\section{Classified Advertising}

\section{NOTICE}

Respondents to advertisers oflering laculty "rank" and "status" are advised that these terms are ambiguous and should inquire as to benefits involved.

All advertisements submitted by institutions offering positions must include a salary range. The range should provide the apolicant with an indication of the salary the institution is willing to provide for the position offered.

All advertisements for the Pasitions Wanted and the Positions Open classifications will be edited to exclude direct or indirect references to race creed color, age, and sex as conditions of employment

Classified advertising orders and copy, and cancellations, should be addressed to the Advertising Department, 50 East Huron Street. Chicago 60611 and should reach that office before the second of the month preceding publication of issue desired. Copy received after that time may be held for the next issue.

Telephone orders for ciassified advertising, while not encouraged because of the increased risk of copy error, will be accepted. Calls should be directed to Leona Swiech at (312) 944-6780. A confirming order should be mailed to the Advertising Department as soon as possible following the call, along with typewritten copy to be used in proofreading the ad.

Rate for classified advertising is $\$ 1.30$ per printed line.

\section{FOR SALE}

UNION LIST OF SERIALS in the Libraries in the Miami Valley. New Fifth Edition now available $\$ 50.00$. Faurth Edition (1973) only $\$ 10.00$. Send order to Sue Campbell, Wright State University Library, Dayton, $\mathrm{OH}$ 45431. Prepaid orders are post paid.

\section{POSITIONS WANTED}

REFERENCE/ADMIN LIBRARIAN seeks work in Vermont, New Hampshire, Massachusetis or NYS. MLS + 4 years experience administrative business or lin. library. Strong ref govt docs media background French \& some German. Pat Bertozzi, 26 E 13 St. NYC. NY 10003.

POSITIONS OPEN

Acquisitions

ACOUISITIONS LIBRARIAN. The Eleutherian Mills His. torical Library, a research library in the field of American

\section{European Book Center is a reliable source for all European Books}

\section{List Prices, Speed and Accuracy}

Send orders or inquiries to:

EUROPEAN BOOK CENTER

P.0. Box 4

1700 Fribourg 2, Switzerland economic, business and technological history, seeks a person to develop retrospective boak, periodical, pamph let, trade catalog and ephemeral collections. Experience with out-ol-print acquisitions is required Prelerence will be given to candidates with demonstrated interest, academic background, and/or research competence in some of the subject specialties of the Library. Necessary cualifications include MLS, advanced work in history or economics, and supervisory experience. Minimum salary is \$9.500. actual depends on experience and training. Applications must be submitted by October for position opening on or about November I, 1976. Mail to Director, Eleutherian Mills Historical Library Wilmington, DE 19807.

Administration

DIRECTOR OF LIBRARIES. Description: Liberal arts college of the Relormed Church in America with over 2,200 students, over 140 faculty, library stalf of 10 (plus student assistants) and holdings of 166,000 volumes; main library and several specialized collections housed elsewhere on campus: linked to OCLC: located in city of 30,000 on Lake Michigan, 130 miles from Chicago. Qualifications: MLS or Ph.D from an accredited library school required, second Master's or Ph.D in subject area desired: minimum of five years' varied library experience. with increasing administrative responsibilities: knowledge of trends in library science: clear understanding of service function of library; appreciation for basic philosophy and goals of college. Terms: 12 month contracti Salary: $\$ 10,000$ minimum dependent on qualifications and experience. Starting date: February 1, 1977: adjustable to July I 1977. Submit curriculum vifae and references by Ocrober 20, 1976 , to Search Commitiee Chairman, Jacob E. Nyenthuis, Dean for the Humanities, Hope College, Holland. MI 49423. An equal opportunity employer.

PUBLIC RELATIONS OFFICER. Administers public relations program: ability to write and speak effectively essential. Requires college degree and minimum three years experience in journalistic/public relations work. MLS desirable. Salary \$11,472-\$15,675. Immediate open ing. Write Personnel Manager, Virginia State Library. Richmond VA 23219. An equal opportunity/alfirmative action employer.

ASSISTANT TRAINING COORDINATOR, Southeastern Library Network. MLS; one year's experience with OCLC system; some travel required. Prefer technical processing experience in an area other than monographic book cataloging; writing and editing ability. Salary: $\$ 10,000-$ $\$ 12,000$. Write to: Kenneth Thomas, SOLINET, Suite 820 615 Peachtree St., N.E., Atlanta, GA 30308.

DIRECTOR OF THE UNIVERSITY LIBRARY. San Jose State University, 50 miles South of San Francisco, has 26,000 students, 1,500 faculty, and graduate programs in over 40 field's. Resources of the library include 700,000 books, exfensive microform holding, a highly developed instructional resources center and a staff of 165 FTE positions. Minimum educational requirements: graduate degree from accredited library school; doctorate and/or advanced degree in subjects field preferred. Minimum professional experience: 8 years as a librarian. including at least 5 years in upper level administrative positions, preferably in an academic library. Demon-
strated ability and knowledge of library and media faculty planning, automation, business management and personnel administration. Salary range: $\$ 27,492-\$ 33,420$ Liberal fringe benefits. 12-month appointment. Closing date: October 1 1976. Send resume to: Dr. Margaret date: October I, 1976. Send resume to: Dr. Margaret of the Academic Vice President, San Jose State University, San Jose, CA 95192. An equal opportunity/affirmative action employer.

DIRECTOR OF LIBRARIES. Ohio University, a stateassisted university of 11,500 undergraduates and 1900 graduate students; small town setting, easy access to large cities. Library holdings of 890,000 ; annual budget $\$ 1,500,000$ : stafl of 21 professionals and 44 classilied employees. Member of OCLC. The Director is responsible for all library activities and policies; functions with the for all library activities and policies: unctions with the library staff; reports directly to Provost. Qualifications: $M L S$ from an accredited library school required; an ad- 
ditional advanced degree preferred. Administrative ex perience in an academic or research library necessary. as well as experience with budget management, direction of personnel; and collection development. Experience in computerized operations desirable. Must possess a strong commitment to faculty and students and have an understanding of the academic mission of the university. Salary range: $\$ 29,000-\$ 35,000$. Send resume and three letters of recommendation by October 31, 1976. Nominations solic ited. Send applications and nominations to: Duane Schneider Chairman. Director of Libraries Search Com mittee, Alden Library Room 512, Ohio University, Athens, $\mathrm{OH} 4570 \mathrm{l}$. An equal opportunity/affirmative action em plover.

DIRECTOR OF LIBRARIES. For academic library of 530,000 volumes, $\$ 1$ million budget serving 10,500 students. Minimum qualifications: ALA-accredited MLS and ad ditional subject master's degree, with Doctorate pre ferred. Five years of diversified library experience in cluding significant administrative responsibilities in an academic library required. Experience and training in computer applications, nerworking, fiscal responsibilities and personnel management highly desirable. Twelve month appointment with full faculty rank. Salary: $\$ 24,000$ $\$ 29000$. Position open September I 1976 . Send letter of application with resume and letters of recommendation to: Library Search Committee, Olfice of Academic Vice President. Sam Houston State University, Huntsville, TX 77340. An equal opportunity/affirmative action employer.

TEACHERS OF LIBRARY AND INFORMATION SCIENCE. Jundi Shapur University in Ahvaz, Iran will begin a M.L.S. program and is looking for instructors with the experience and ability to successfully implement the program, as well as to continue working towards the development of the existing library collection. The basic requirements are a MLS degree with at least fwo years experience or a MLS degree and a Ph.D (preferably in Library Science or a related field) with teaching experience. We are especially interested in applicants with specializations in information science. The monthly salary for holders of the MLS is 92,000 Rials (about $\$ 1,300$ ) and 125,525 Rials (about $\$ 1,700$ ) for holders of the Ph.D. Send resume official University transcripts and three letters of recommendations to: The College of Literature and
Humanities. Jundi Shapur University, P.O. Box 257, Ahvaz, Iran

D|RECTOR OF LIBRARY, New England liberal arts college of 1,600 students: 325,000 volumes in main library specia collections and departmental libraries; professional staff of seven. Starting date: summer or fall of 1977. The library is expanding use of media programs and data processing systems (including OCLC). Its director should be familiar with current trends in ibrary developments and with grant programs; able to coordinate resources and to work well with students, faculty, and staff. MLS from ALA-accredited library school: advanced subject degree or Ph.D in library science: substantial experience including administrative responsibilities in college university libraries. Salary $\$ 19,500+$, dependent on qualilications and experience: 12 month contract, faculty status: comprehensive fringe benefits including TIAA/CREF. Send resumes, including names and addresses of references, before November I, 1976 to Dean Paul Jenson, Colby College, Waterville, ME 0490I. An equal opportunity/ affirmative action employer.

HEAD LIBRARIAN, Union College. Candidates should possess an accredited professional degree in librarianship or its equivalent and successful administrative and practical experience in an academic or research library. Additional qualifications include familiarity with library automation processes and information retrieval services. Evidence of a strong commitment to scholarship is essential. Faculty status and rank: twelve-month contract with one month of vacation. Salary: $\$ 18,000-\$ 25,000$. Liberal fringe benefits. Letters of inquiry and resumes. including the names of three references should be sent by Octaber I, 1976 to Professor David Potts, Chairman Librarian Search Committee Social Sciences Building Union College, Schenectady, N.Y. I2308. Union College is an equal opportunity/affirmative action employer.

LIBRARY, ASSOCIATE DIRECTOR of Learning Resources for starting $10 / 1 / 76$ or after. MLS plus additional gradu ate $\mathrm{A} / \mathrm{V}$ courses. Plan, administer, evaluate, program w/enrollment of 5,000 FTE. Twelve months salary, $\$ 17,000$ minimum, based on experience. Reply immediately in writing only to Director of Employee Relations. Hudson Valley Community College, Troy, NY 12180 . An equal opportunity/affirmative action employer $M / F$

\section{Całaloging}

CHIEF, CATALOG DEPARTMENT. This person defines goals, sets policies and makes plans for the Cafalog Department (total stall of 52 FTE including 23 professionals) in areas of personnel, budget and physical resources; contributes to library-wide planning and management and coordinates activities with other senior managers. The position requires MLS from ALA-accredited graduate library program or equivalent: requires demonstrated ability to manage large groups (5 years experience managing technical services operations in a major research library will be evidence of this ability); requires experience in applying automation techniques to library technical processing operations: requires demonstrated initiative and leadership excellence; requires knowledge of bibliographic organization and access principles and understanding of the role of national library services: requires ability to communicate well orally and in written form: requires knowledge of and commitment to programs of Affirmative Action. Initial salary between $\$ 20,000-\$ 24,000$. For information apply to Tina Kass, Library Personnel Olfice, Stanford University Libraries, Stanford, CA 94305, by October 15, 1976. An equal opportunify/affirmative action employer.

CATALOGER. Responsible for oriainal cataloging of monographs and serials in the Hebrew language. May be asked to catalog in other languages as needed. $R$. quires: a graduate degree from an accredited library school; two or more years of cataloging experience in a university libraryi a thorough knowledge of Hebrew and a working knowledge of another foreign language. Minimum salary: $\$ 11,500$. Available: August 1, 1976. Send resume to: Miss Jane Titus. Personnel Librarian, Paley
Library, Temple University, Philadelphia, PA $19 / 22$ An equal opportunity employer

LIBRARIAN-CATALOGER. To do original cataloging. Desired qualifications in order of importance: ALA ac credited master's degree in library science. At least two years experience in cataloging. Background in science and technology. Knowledge of MARC format. Familiarity with OCLC cataloging. Foreign language facility. Salary $\$ 10,000$ or more depending on qualifications. Position presently available. Request appropriate forms from John Thomas, Personnel Officer, Libraries and Audio Visual Center, Stewart Center, Purdue Universify, West Lafayette, IN 47907. Only complete credentials will be reviewed. Credentials include: completed application resume, transcripts letters of recommendation and olace ment papers from library school. Deadline for applications September 30, 1976. An equal opportunity employer.

CATALOGER: $\$ 890-\$ 1200 /$ month monograph cataloging position available immediately. The incumbent prepares original cataloging copy and assists with difficult partial copy catologing for OCLC computer terminal input; uses LC classifjeation and LC subject headings. Master's degree from an ALA-accredited school meets basic qualification sought; additional master's degree in a subject field and reading knowledge of German and Slavic languages desired; two or more years of experience prelerred; ability to work effectively with others. Appointment made with laculty rank: academic fringe benefits provided. Expected to meet research and publication requirements of the University. Send resume to Ronald P. Naylor, Acting Director of Libraries, University of Houston, 4800 Calhoun Rd. Houston, TX 77004. An equa opportunity/affirmative action employer.

CATALOG LIBRARIAN. Academic library serving approximately 21000 graduafe and undergraduate students. Ap pointment at the rank of instructor or assistant professor. Twelve month contract at \$12,000-\$13,400. Twenty-four days annual leave. REQUIREMENTS: Accredited MLS: minimum of two years cataloging experience. OCLC and A-Y cataloging experience desirable. Send application and resume to Bob Sun, Head, Catalog Department, Memphis State University, Memphis, TN 38152, no later than Sep tember 15, 1976. Equal opportunity employer.

CATALOG LIBRARIAN/Head of Central Catalog Department serves Health Sciences and general Academic Library. Initial responsibility for original health sciences cataloging and departmental administrafion. Minimum o 5 years experience. Combined health sciences and genera academic cataloging background preferred. SOLINET/ 
OCLC Member. Faculty status, paid BC/BS. Salary negotiable from $\$ 12,000$ up. An equal opportunity/affirma. tive action employer. Send resume to: Mr. Connor D. Tiarks, Assistant Director, Central Processing Division, Virginia Commonwealth University Libraries, 901 Park Ave nue, Richmond, VA 23284

Multiple

THREE POSITIONS: I ASSISTANT SCIENCE LIBRARIAN, Science Division. Reference position including interlibrsry loan. Supervision of the Map Room. Assist with development of the resources of the Division for instruction and research. University reference experience preferred. Some evening work. Bachelor's and/or master's degree in scientific area. Language-German. 2. SCIENCE CATALOGER, Catalog Department. Subject descriptive cataloging o books, microlorms, and tape cassettes in science, lechnology and share education. Dewey classification. University cataloging and/or OCLC experience preferred. Language-German, Temporary one year appointment. 3. MUSIC CATALOGER, Catalog Department. Subject and descriptive cataloging of music, books, and recordings, Dewey classilication except for recordings. University cataloging and/or OCLC experience preferred. Bachelor's and/or master's degree in music. Language-working knowledge of German, French and Italian. All positions require MLS from ALA-accredited library school. Faculty rank and salary commensurate with qualifications but minimum \$10.500. Participation in University Retirement System of lilinois, state paid life, hospital and surgical insurance. 37-hour work week; 25 vacation days: 60 calendar days sick leave per contract year; 12-month appointment. Available I September 1976. Send letter of application to Sidney E. Matthew5, Assistant Director, Morris Library, Southern Illinois University, Carbondale IL 6290I. An equal opporfunity/affirmative action em ployer.

\section{Reference}

REFERENCE LIBRARIAN. Provide reference service, including computerized literature searching in humanities and social sciences. Primary responsibility for development of comprehensive orientation and instruction program lor the General Library. Coordinate instruction activities of other relerence stafl, advise and train colleagues in instructional techniques including use of audio-visual equipment. Required: MLS. Reference ex perience in academic library. Experience with instruction programs in academic environment essential. Training experience in computerized literature searching desirable. Benelits: Libraries are academic appointees. 24 days annual vacation. Usual benefits. Rank: Assistant Librarian $(\$ 12,312-\$ 15,804)$ or Associate Librarian $(\$ 15,096-\$ 21,708)$. Position open: October I. 1976. Write to: Margaret Scholt, University of California, P.O. Box 5900, Riverside, CA 92507. An equal opportunity/affirmative action emplover.

\section{Subject Specialists}

SCIENCE/TECHNOLOGY LIBRARIAN. Directs a branch Science/Technology Library of 120,000 volumes. Typical duties include: coordination and supervision of public services, including a circulation system; maintenance of serials, records and a public catalog; selection and appointment of stalf; development of policies for services, facilities and resources for the branch: service as liaison for the Midcontinental Regional Medical Library Program (MCRML). This branch might also expand within two years to serve a new medical program. Experience desired includes: several years of successful management with increasingly responsible duties in a medium to large science collection/branch: experience with or knowledge of computer-based information retrieval systems: demonstrated ability to work elfectively with laculty, students and staff. Master's in library science from an ALA accredited school; second master's in science preferred. but substantive middle management experience may be substitured. Position carries full faculty status and responsibilities. Salary $\$ 15,000$ minimum, depending on qualifications. Deadline for applications: October I, 1976. Apply to: Robert H. Patterson, Director of Libraries University of Wyoming, Laramie, WY 8207I. An equal opportunity/affirmative action employer.

ETHNIC STUDIES REFERENCE LIBRARIAN. MLS from an accredited Library Schoo: demonstrated sensitivity to and a high degree of familiarity with the culture of the
Southwest: a knowledge of Reference materials. Assists students, faculty and community, especially those minorities of ethnic background in general library usage: possesses the ability to identify all type of material and information, and to compile bibliographies of ethnic studies resources, including Spanish language materials: supervisory experience desirable. Faculty status with 12 month contract. Salary: $\$ 10,500-\$ 12,500$ depending on qualifications and experience. Available July 1976 . application deadline September 15, 1976. Send resume to Beatrice Hight, Chairperson, Search Committee, Zimmer man Library, University of New Mexico, Albuquerque, NM 87I3I. An equal opportuniry/affirmative action em. ployer.

BIBLIOGRAPHER to assist in collection development (psychology/sociology/anthropology). Also, some origina cataloging (10-15 hours wk.). Accredited MLS, appropriate social science background. Some cataloging experience. Minimum I year prolessional academic library experience. Salary $\$ 11,000+$. Faculty rank. Apply by Oct. I 1976 to F. Edwin Johns, University Library Office, $\mathrm{Rm}$. 126 Wright State University, Dayton, $\mathrm{OH} 45431$. An equa opportunity/affirmative action employer.

BIBLIOGRAPHER to assist in collection development in biological sciences and nursing. Also responsible for al! general out-of-print material: o.p. experience essential. Accredited MLS: second master's in biological sciences prelerred. Minimum 2 years prolessional academic library experience. Salary $\$ 11,500+$. Faculty rank. Apply by Oct. I, 1976 to: F. Edwin Johns, University Library Office, $\mathrm{Rm}$. 126, Wright State University, Dayton $\mathrm{OH} 45431$. An equal opportunity/affirmative action employer.

SCIENCE LIaRARIAN II. Stanford University Libraries, $J$. Henry Meyer Memorial Library. Salary $\$ 12,600-\$ 15,000$. Responsibilities: Responsible for providing undergraduate reference assistance, selecting library materials, primarily in Science and Technology, and coordinating all Meyer Library collection activities. Qualifications: MLS from an ALA accredited library school or equivalent required academic background and/or library experience in natural or physicial sciences required: 3-5 years public service experience in an academic or special library required; knowledge of and concern for undergraduate education required. Candidates should supply with their first letter a complete statement of their qualifications: a full resume of their education and relevant experience as well as 3 names of references who are knowledgable of their qualifications for this position. Closing date for application November I, 1976. Lettes and documents should be addressed to Tina Kass Library Personnel Officer, Stanford University Libraries, Stanford, CA 94305. An equal opportunity/affirmative action employer.

ASSISTANT PROFESSOR AND SPECIAL COLLECTIONS LIBRARIAN: Responsible for the development, organiza. tion, administration and promotion of the library's special collections, including archives: provide liaison with Friends of the Library and potential donors. Qualifications: MLS from ALA-accredited Library School, 3 or more years of relevant experience, knowledge of archival organization, Master's desirable Salary: $\$ 12,000-\$ 14,000$. Application deadline $9 / 15 / 76$. Position starts October I. 1976. Send resume and three letters of recommendation to Dr. Donald E. Vincent, Professor, University Librarian, Diamond Library, University of New Hampshire, Durham, $\mathrm{NH}$ 03824. An equal opportunity/affirmative action employer.

Technical Services

LIBRARIAN for TECHNICAL SERYICES. To coordinate, organize and administer the Technical Services Division of the Milton S. Eisenhower Library including the Acquisitions, Search, Catalog and Serials sections. The division has a staff of 9 professionals and 22 paraprofessionals-clerical, to develop and formulate effective policies and procedures for the division and to coordinate with other divisions of the library. Must have MLS from an accredited library school: at least 5 years' experience in positions of increasing of responsibility in technical services in academic libraries; experience with OCLC cataloging system. A master's degree in a subject field would be an added advantage. Salary $\$ 18,000$ minimum but negotiable based on qualifications. Excellent benefits. Send resume including salary history to the Johns Hopkins University, Office of Personnel Services, Room 146, Garland Hall, 34th and Charles Street, Baltimore, MD 21218. An equal opportunity/alfirmative action emplover. 
outstanding art periodicals with pre-publication discounts

\section{Apollo}

The Magazine of the Arts.

now available:

Vols. 1 - 20. London, 1925 - 1934 . clothbound SFr. 4405.50

now on press - available December 1976:

Vols. 21 - 90. London, 1935 - 1969. clothbound SFr. 12787.50

Vols. 24 -90. London, 1936 - 1969; include the advertisement sections on microfiche. The ca. 220 microfiche are also available separately at SFr. 3.75 per fiche.

A pre-publication discount of $5 \%$ is granted on all orders received before 30th November, 1976.

\section{Oud Holland}

Quarterly for Dutch Art History.

now available:

Vols. 1 - 27. Amsterdam, 1883 - 1909.

clothbound SFr. 2539.50

now on press - available October 1976:

Vols. 28 - 86 \& Gen. Ind. 1 - 60. Amsterdam, 1910 - 1971.

clothbound SFr. 5554.50

A pre-publication discount of $5 \%$ is granted on all orders received before 31st October, 1976.

\section{KRAUS REPRINT}

FL-9491 Nendeln, Liechtenstein / Route 1000, Millwood, N.Y. 10546 


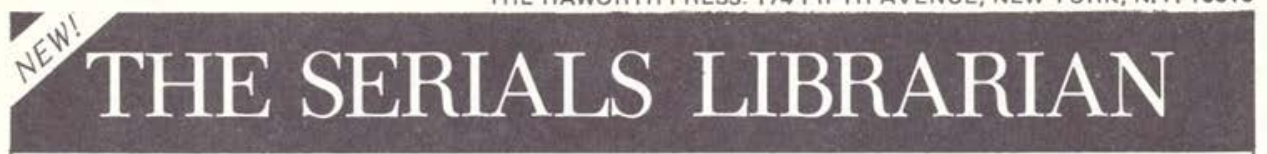

the quarterly journal of serials management

\section{EDITOR: Peter Gellatly \\ Head, Serials Division \\ Univ. of Washington Libraries}

NEWS EDITOR: Gary Pitkin

Head, Serials Department

The Bierce Library

University of Akron

THE SERIALS LIBRARIAN is a new quarterly journal created specifically for serials librarians and all library professionals who work with serials publications. This new journal provides fresh and pertinent articles in such areas as:

- serials selection \& acquisitions

- claiming, binding, storage

- cataloging $\&$ bibliographic control

- economic management \& collection development - interlibrary loan

- relations with serials publishers

- relations with subscription agencies

- renewals, backorder problems, microfilming

Each issue of THE SERIALS LIBRARIAN also provides a comprehensive news section to keep serials librarians up-to-date on new technology, recent symposia, new tools, etc., and a valuable Current Abstracts on Serials section, covering articles on serials librarian. ship published elsewhere.

\section{Table of Contents -}

$$
\text { Vol. I, No. } 1 \text { (Fall 1976) }
$$

Joining Art and Technics at theiserials Desk by Bill Katz, Ph.D., Prof, of Library Science, SUNY at Albany, \& Editor, Magazines for Libraries

Mulling Over Mencken's "Mercury" by Harry C. Bauer, Professor Emeritus, School of Librarianship, University of Washington (Seattle)

Entry of Serials by Mary Ellen Soper, School of Librarianship, University of Washington (Seattle)

The Subscription Agency and Lower Serial Budgets by Frank F. Clasquin, Vice President, F.W. Faxon, Inc.

Microform Serials Collections: A Systems Analysis by R.J. Coffman, Director of the Northeastern University Library

Unique Identifiers for Serials: An Annotated, Comprehensive Bibliography by Elizabeth $\mathrm{H}$. Groot, Librarian, Schenectady Chemicals, Inc.

An 18th Century German Library Inventory of Serials by Paul Kaufman, Ph.D., Bibliographic Consultant, University of Washington Libraries

Copyright: Colloquium Notes by Robert J. Baynham, Attorney-at-Law, and Marian G. Gallagher, Law Librarian, University of Washington

SERIALS NEWS

CURRENT ABSTRACTS ON SERIALS

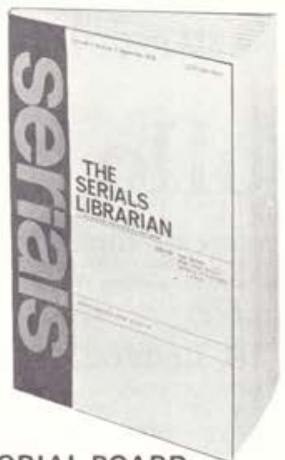

EDITORIAL BOARD:

Toni Carbo Bearman, Executive Director, National Federation of Abstracting \& Indexing Services William K. Beatty, Professor of Medical Bibliography, Medical School, Northwestern University

Susan Brynteson, Associate Director for Technical Services, University of Tennessee Libraries Marietta Chicorel, President, Chicorel Library Publishing Corporation

Frank F. Clasquin, Executive Vice President, F.W. Faxon Company

Sidney Cohen, History Department, Louisiana State University

Robert J. Cross, Assistant Director for Public Services, Western Washington State College

Henry Drennan, U.S. Office of Education, Washington, D,C.

Paul J. Fasana, Chief, Preparation Services, New York Public Library

Ralph Franklin, Bibliographic Systems Consultant, Washington State Libraries

Jean M. Higginson, Senior Planning Officer, Research \& Planning Branch, National Library of Canada

Daphne Hoffman, Systems Librarian, Oregon Reg. List of Serials, Portland State Univ. Library

William H. Huff, Serials Librarian, University Library, University of Illinois

Ellsworth Mason, Rare Books Librarian, University of Colorado

Perry D. Morrison, Professor of Librarianship, University of Oregon (Eugene)

Huibert Paul, Serials Librarian, University of Oregon Library

Grant T. Skelley, School of Librarianship, University of Washington (Seattle)

Eleanor P. Vreeland, Vice President, StechertMacMillan, Inc.

Hans H. Weber, Assistant Director for Technical Services, University of Houston Libraries

Please enter our subscription to THE SERIALS

LIBRARIAN, Vol. I (Fall 1976 - Summer 1977)

( ) $\$ 18.00$ enclosed (4 issues + Index)

( ) please bill us (plus postage $\&$ handling)

( ) institutional purchase order attached

The Haworth Press 174 Fifth Avenue New York, N.Y. 10010

Name

Library

Address

City State Zip

Canadian orders: add $\$ 2.00$ postage \& handling Other foreign orders: add $\$ 5.00$ postage \& handling 